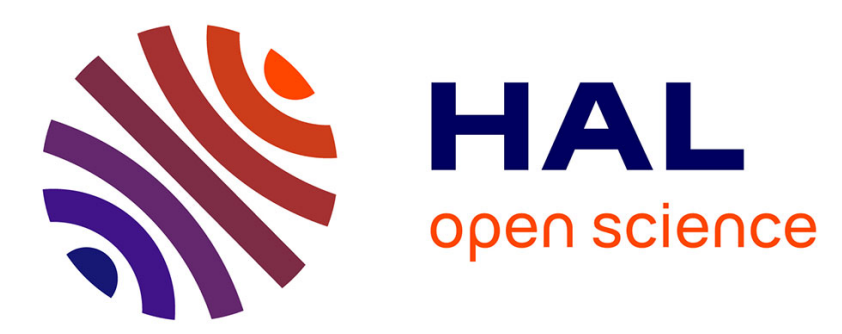

\title{
Collective Learning, Effective Demand, Loss of Work and Loss of Direction: The Growing Regional Divide in the UK
}

Ross Mackay, Rhys Davies

\section{- To cite this version:}

Ross Mackay, Rhys Davies. Collective Learning, Effective Demand, Loss of Work and Loss of Direction: The Growing Regional Divide in the UK. Regional Studies, 2011, pp.1. 10.1080/00343404.2010.543128 . hal-00676996

\section{HAL Id: hal-00676996 https://hal.science/hal-00676996}

Submitted on 7 Mar 2012

HAL is a multi-disciplinary open access archive for the deposit and dissemination of scientific research documents, whether they are published or not. The documents may come from teaching and research institutions in France or abroad, or from public or private research centers.
L'archive ouverte pluridisciplinaire HAL, est destinée au dépôt et à la diffusion de documents scientifiques de niveau recherche, publiés ou non, émanant des établissements d'enseignement et de recherche français ou étrangers, des laboratoires publics ou privés. 


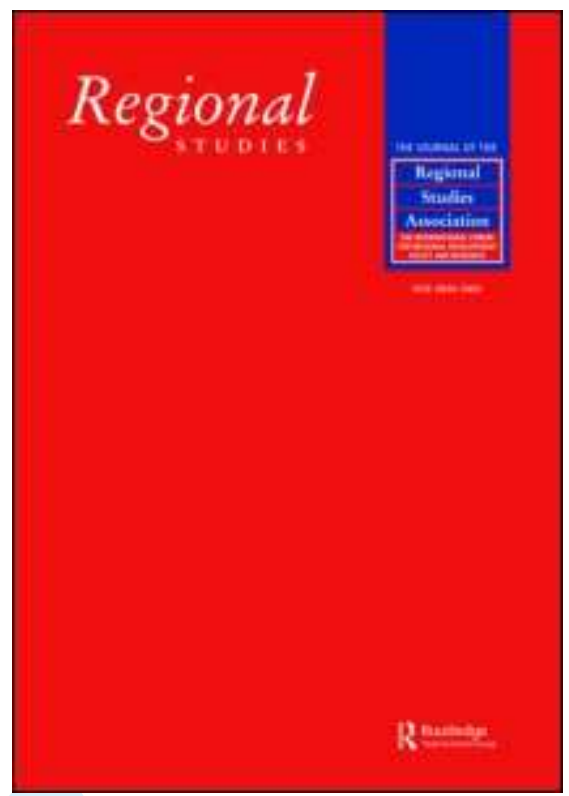

\section{Collective Learning, Effective Demand, Loss of Work and Loss of Direction: The Growing Regional Divide in the UK}

\begin{tabular}{|r|l|}
\hline Journal: & Regional Studies \\
\hline Manuscript ID: & CRES-2010-0104.R1 \\
\hline Manuscript Type: & Main Section \\
\hline & $\begin{array}{l}\text { E65 - Studies of Particular Policy Episodes < E6 - Macro Policy } \\
\text { Formation, Macro Public Finance, Macro Policy, etc < E - } \\
\text { Macroeconomics and Monetary Economics, J23 - Employment } \\
\text { Determination; Job Creation; Labor Demand; Self-Employment }< \\
\text { J2 - Time Allocation, Work Behavior, and Employment } \\
\text { Determination/Creation < J - Labor and Demographic Economics, } \\
\text { J24 - Human Capital|Skills|Occupational Choice|Labor Productivity } \\
\text { J J2 - Time Allocation, Work Behavior, and Employment } \\
\text { Determination/Creation < J - Labor and Demographic Economics, } \\
\text { R58 - Regional Development Policy < R5 - Regional Government } \\
\text { Analysis < R - Urban, Rural, and Regional Economics }\end{array}$ \\
\hline Keywords: & $\begin{array}{l}\text { Regional Development, Fiscal Policy, Labour Demand, Human } \\
\text { Capital }\end{array}$ \\
\hline
\end{tabular}

\section{SCHOLARONE Manuscripts}




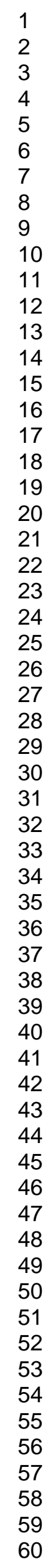 \\ Page 1 of 39}

1

2

4

5

7

8

10

11

12

14

15

16

18

19

20

22

23

25

26

27

29

30

32

33

35

36

37

39

40

41

42

44

45

46

47

48

49

51

52

53

54

55

57

58

59

60

http://mc.manuscriptcentral.com/cres Email: regional.studies@fm.ru.nl 
Collective Learning, Effective Demand, Loss of Work and Loss of Direction: The Growing Regional Divide within the UK

Ross R MacKay ${ }^{\mathrm{a}}$ and Rhys Davies ${ }^{\mathrm{b}}$

\author{
${ }^{a}$ Bangor Business School, Bangor University, Bangor, Gwynedd LL57 2DG. Email: \\ christine.mackay12@btinternet.com \\ ${ }^{\mathrm{b}}$ Wales Institute for Social and Economic Research, Data and Methods (WISERD), \\ Cardiff University, 42 Park Place, Cardiff CF10 3BB. Email: \\ daviesor@cardiff.ac.uk
}

(Received March 2010: in revised form October 2010) 
Abstract

The local economy relies on a division of labour that develops highly specialised skills. In searching for an understanding of the growing work gap within the United Kingdom, emphasis is placed on recessions that connect to loss and redundancy of physical and human capital. High levels of regional unemployment following deindustrialisation convert into high levels of regional nonwork in later years. Loss of economic base leaves a gap in the community and economy that people struggle to bridge. Market forces work strongly against certain groups in society, including those at some disadvantage in the labour market.

JEL: E65, J23, J24, R58

Key words: Regional Development, Fiscal Policy, Labour Demand, Human Capital 
Collective Learning, Effective Demand, Loss of Work and Loss of Direction: The Growing Regional Divide in the UK

1. Introduction

"There is no craving or demand of the human mind more constant and insatiable than that for exercise and employment" (Hume,[1752] (1963), p.189)

"Human capital deteriorates when it is idle, because unemployment impairs the skills that workers have acquired" (Schultz, 1961, p.13)

Work builds us (Hume), unemployment and inactivity reduce us (Schultz). We are what we do and we are more content and lively when we are employed in systematic, sustained, methodical labour. Work adds to mental vigour and harnesses hidden potential: it is a civilising influence that satisfies our craving for involvement, adds to the quality of leisure and shields us from unhealthy appetites. The potential return from work is central to Hume's political economy and to his understanding of human nature and civil wellbeing.

The key argument for full employment, Beveridge (1944, p.19) claimed, is that "A person who cannot sell his labour is in effect told that he is of no use". In the United Kingdom economy, the problem of lasting loss of contact with work is wider than measured unemployment. There has been a strong shift from unemployment to inactivity. It is enduring loss of contact with work that has an adverse effect on skill, discipline, good habits, self-confidence and self-respect. It is inability to find work 
and particularly loss of contact with the labour market that has an adverse effect on labour quality and labour potential.

Economics and wealth creation embrace more than the efficient use of known, scarce resources. Also important is resource creation, the employment and improvement of resources of unknown potential. In Smith's Wealth of Nations, capital and knowledge accumulation provide the keys to growth. Capital includes "the acquired and useful abilities of all the inhabitants of the nation" (Smith, 1776, p.264). Adam Smith insists that it is combined labour that adds to human capital, to productivity and to wealth. Labour's productive power, "the greater part of skill, dexterity and judgement ... [are] the effect of the division of labour" (Smith, 1776, p.51). The division of labour depends on the extent of the market and this, in turn, depends on 'effectual demand' for goods and services. The division of labour is dynamic and it is central to acquiring skill and knowledge. We learn by doing and output and earnings are raised by knowledge of fellow workers, by experience in work and by improved understanding of the best way to do things. The learning process is a voyage of discovery and the local economy relies on a division of labour, both within and between firms, which develops highly specialised skills and perceptions.

This article concentrates on trends in male work, unemployment and permanent sickness since 1971. It draws on contrasts between the Keynesian Golden Age, 1950-73, and later years. Part 2 concentrates on data from the 2001 Census of Population. The 2001 data show considerable regional variation in work (effective demand) levels and in regional inactivity, but little variation in regional unemployment. Those who find it difficult to compete in low opportunity labour markets lapse onto sickness benefit, or are eased onto other forms of inactivity. In 
slack labour markets, labour supply (employment, self employment and measured unemployment) is lower than potential labour supply.

In searching for an understanding of the growing work gap within the United Kingdom, parts 3 and 4 of this paper places considerable emphasis on recessions that connect to loss and redundancy of physical and human capital. The recession of 1973-74 is important because it signals a move to lower growth levels in most, if not all, mature industrial economies. But it is the recession of 1979-83 that contributes to a substantial divide in regional unemployment and economic opportunity. Creative Destruction is Schumpeter's elegant description of structural change (Schumpeter, 1943). Economic growth is not more of the same, Schumpeter insists, and the elimination of the old is part of progress. It is, however, sensible to try and avoid concentrated, cumulative loss. The themes of orderly retreat, phased decline, and regional balance were not part of economic policy in the early 1980s. The unemployment increases of 1979-86 developed from steep decline in industrial employment and they were unevenly distributed and convert into high levels of regional nonwork in later years (see Part 4) Part 5 considers the year-by-year evolution of a substantial work, wage and productivity gaps within the UK. Part 6 concludes. Human capital deteriorates when people are idle and in low opportunity labour markets many are excluded. Loss of economic base leaves a gap in the community and economy that people struggle to bridge.

2. The 2001 Census, Effective Demand and Measured Sickness 
'Movement out of the statistical labour force when demand is low may be regarded as a form of concealed unemployment,' (Dow 1964, p. 338).

Retreat from effective regional policy across a number of European countries, Läpple (1985) claims dates from around 1973 - the end of the Keynesian Golden Age. Regional imbalance became severe when nation states silently and to some extent reluctantly abandoned commitment to both full employment and effective regional intervention. In Table 1, the 3 poorest regions in Britain (Wales, North East and North West) are combined as one unit, Wales and North and are compared with the 3 most prosperous British Regions, the Inner Region Core (IRC) comprising London and its 2 major commuting regions, the East and South East. By the end of the Keynesian Golden Age output per head in Wales and North was $84 \%$ of the IRC level, by the turn of the century only $69 \%$. The output gap between the poorest and most prosperous parts of Britain doubled. Since output (value added) feeds income and supports expenditure it is no surprise to discover that other regional data including earnings, household expenditure and work levels also identify a substantially enhanced regional divide. But there are two striking results in Table 1. Firstly, comparing Census data for 1971 and 2001, in Wales and North the share of the male work age population (excluding students) in work falls from $90 \%$ in 1971 to only $75 \%$ in 2001, but the male unemployment level is lower in 2001 than in 1971. Second, comparing 1971 and 2001, there is a growing work gap between IRC and Wales and North, but the unemployment gap falls. Census unemployment data fails to register the growing regional divide. 
Table 1 goes here

The answer to the puzzle connects to the discouraged worker effect; the substitution of inactivity for unemployment. Movement out of the labour force ensures that labour supply (employment, self-employment and unemployment) falls below potential labour supply when demand is low. The discouraged worker effect is highly sensitive to effective demand for labour in the local, regional, or national economy. In low opportunity labour markets where competition for jobs is fierce, some workers lose faith in job search and lose contact with the labour market. The potential workers who retreat from the labour market may retire early, continue in education, return to education, accept government training, substitute household work for search for employment, or lapse into debility and measured sickness. By the beginning of the $21^{\text {st }}$ century, the discouraged worker effect is more substantial than measured unemployment and dominated by those out of work who describe themselves in the as permanently sick or disabled (see MacKay and Davies, 2008). Divorce from the working population concentrates on those who are ill-equipped to compete and includes the less healthy, the less well qualified, the poorly motivated, those with limited educational qualifications and the elderly. The longer the spell out of work, in whatever form, the lower the probability of return to work. Adverse selection cuts deep in slack (soft) labour markets and the ripples and impacts reach well beyond the labour market (see Rowthorn and Webster, 2008).

Given the Keynesian approach, effective demand depends on the demand for goods and services produced by the economy. Effective demand failures take two forms. First, the potential availability of workers is not an actual demand for goods and services. Unemployed and discouraged workers cannot encourage the product 
(and labour) market to recognise that they embody hidden, unsatisfied demand that will only become effective when workers are employed. Second, private investment in technically specialised, invention-vulnerable, market-dependent, concrete and durable plant and equipment is, by its very nature, volatile, capricious, unreliable. Investment depends on a future that is more than uncertain, it is unknowable. Since future returns are vague, confidence is unstable and investment depends on intuition, on the news, on animal spirits and on an urge to action rather than inaction. The natural consequence is that investment 'fluctuates widely from time to time' and from region to region (Keynes, 1973c, p.118).

In Figure 1, regional work levels for males are the indicators of regional effective demand. Work is employment and self-employment. As we move from left to right in Figure 1 (as work levels rise) permanent sickness and unemployment fall, but permanent sickness is notably more sensitive to variation in regional work (effective demand) levels. Simple regressions suggest that each $1 \%$ rise in male work level reduces permanent sickness by 0.63 percentage points and unemployment by 0.26 percentage points. Similar patterns are observed for women. Figure 1 demonstrates that in regions of low levels of effective demand for labour there is a strong tendency for limited opportunity to take the form of measured sickness rather than measured unemployment. The greater the degree of labour market disadvantage (the lower the work level) the less appropriate is unemployment as a measure of labour market slack.

Figure 1 goes here

3 Full Employment No More: An End to Regional Balance. 
'Several million men in England will - unless another war breaks out - never have a real job this side the grave' (Orwell, 1936, p. 162).

'If we can cure unemployment for the wasted purpose of armaments we can cure it for the productive purposes of peace. Good may come out of evil' (Keynes, 1973b, p. 532).

The war proved that the jobless were capable of work and it provided a rationale for regional policy and also for full employment. Rearmament and the strategic needs of the war economy encouraged relocation of industry to less vulnerable and more remote parts of the United Kingdom. That experience and 'the euphoria' of the post war years encouraged continued relocation between 1945 and 1951 (Hennessy, 1993, p.209). Careful comparisons of relative cost in parent and branch plants came to the conclusion that there were teething and adjustment costs, but no continuing cost disadvantage attached to plant movement (Luttrell 1962). Relocation within a notably compact and confined nation state was an acceptable and low cost response to 'the task of shifting men from industries where they are permanently redundant' (Keynes, 1973a, p.89). Economic growth is a learning process, employees have specialised and specific skills and there is collective learning: but, given investment and opportunity, workers grow into a different culture. Strong regional policies in the years 1945-51 and 1963-73 demonstrated that workers from farms, mines, quarries, shipyards and steel adapted readily to the needs of growth industries.

Growth depends on innovations and these destroy even as they create.

Creation and destruction are component parts of economic development, but they tend to be geographically separate. The innovators do not habitually emerge from the firms and industries that linger on 'in the fatally deepening dusk of respectable decay' 
(Schumpeter, 1939, p45). Growth that relies on the spontaneous evolution of innovational investment is highly uneven: market-driven capitalism can produce deep regional divisions; it is 'lopsided, discontinuous, disharmonious by nature' (Schumpeter, 1939, p. 102). Creation and innovation, the introduction of new methods and new products, is embedded in new plant and equipment designed to introduce best-practice techniques and new plant and new capital equipment have a productivity advantage akin to the most fertile land (Salter, 1969). The carrots (financial inducements) and sticks (location controls) of regional policy encouraged relocation of innovative growth industries and connected the high unemployment locations to a more optimistic dynamic (MacKay and Thompson 1979).

Keynes (1973b,p.386) described regional policy as the search for 'a rightly distributed demand', the Board of Trade equivalent was 'a proper distribution of industry'. A regional policy that sought to influence the location of industrial expansion was heavily dependent on both full employment and manufacturing growth. Spatial redistribution declined as the national economy drifted to higher levels of unemployment in the late 1960s and early 1970s. It became notably less significant after the oil price shocks of 1973 and 1974. Commitment to full employment followed from the shared sacrifices of the war years, but it also relied on the Keynesian Revolution in economic thought and understanding. Keynes (1973, p. VIII) described the evolution of his ideas as a 'long [and laborious] struggle of escape' from assumptions and thought processes that guaranteed market clearing. The most important determinant of output and employment is aggregate effective demand. In the first 18 years of the Golden Age, 1950-67, we have a sellers market for labour (Table 2). Given growth and low unemployment, a great deal of structural decline could be absorbed by natural wastage (voluntary quits and retirements). Low 
unemployment added to constructive labour mobility, to adaptability and to flexibility. Up to the late 1960s control of inflation was guided by workers and unions who placed a high value on job security and were willing to accept wage restraint because they remembered the hard times in the 1930's and in the war years (see Phelps Brown, 1983; Worswick, 1992). In due course control over the Union movement shifted to a more militant generation with experience only of full employment and who believed that governments feared unemployment and would continue to accept responsibility for the level of effective demand. There was a jump in the rate of money wage increases in a number of European countries in the late 1960s; the revolution of rising expectations was seen not only in pay increases, but also in a wave of industrial unrest and civil protest which was international. In the years from 1968 the UK and other European countries began to lose touch with full employment.

Table 2 goes here

The real substantial check to output growth and the end of the Keynesian Golden Age comes in 1973. Prior to the oil price increases, most people expected continued growth; after 1973 there was doubt and uncertainty. The reduction in growth and the increase in unemployment were international. Maddison (1991) provides data for 16 capitalist economies. In his 16 prosperous economies, the arithmetic average for annual improvement in real GDP per head was $3.8 \%$ in the years 1960-73 and only $1.9 \%$ between 1973 and 2001. In the UK average annual growth fell from $2.5 \% 1950-73$ to $1.7 \%$ 1973-2001. The oil price increases added to inflation and unemployment. With inflation at uncomfortable levels demand 
management was difficult. A price standard (low and stable inflation) emerged and, in time, displaced the labour standard of full employment. With inflation seen as the main threat, demand management was 'not available to sustain output and employment' (Worswick, 1992, p.61).

The major step to high unemployment and a buyers' market for labour comes with OPEC recession 2 (oil prices doubled in 1979-1980) and deindustrialisation. By the mid 1980s, full employment was a distant memory. The growing influence of the price standard (low inflation) is a product of historical circumstance, but it also owes a great deal to the Counter Revolution in economic ideas that developed as a critique of the Keynesian Revolution and demand management. The Counter Revolution has three articles of faith: (1) markets, including labour markets clear - only misinformation and confused signals prevent labour markets from arriving at market clearing wages; (2) private expenditure is good, public expenditure is bad; (3) voluntary unemployment can be reduced by making unemployment less attractive. In his contribution to the Treasury Report on Monetary Policy, Friedman concluded that 'only a modest reduction in output and employment will be a side effect of reducing inflation to single figures by 1982' (Treasury, p. XXXV1). Friedman also claimed that reduction of Government spending by one sixth 'is not a major magnitude'. It makes people available for productive employment and most 'would be absorbed in a fairly brief period' (Friedman, 1977, p.47). Tobin was less optimistic In a summary of his evidence to the Treasury Committee, Tobin warned that disinflation would be a 'lengthy and costly’ process, 'characterised by deep recessions, stunted recoveries and high and rising unemployment' (Tobin, 1983, p.297). Tobin anticipated unemployment that was deeper and more distressing than the Counter Revolution 
anticipated: the recovery powers of the market could easily be exaggerated. Table 2 points to the significant rise in unemployment in the first half of the 1980s.

\section{Deindustrialisation - A Lasting Impact}

'In major recessions under employment results in the deterioration and premature scrapping of physical equipment ... the capital stock, physical and intangible ... takes time to build up and its destruction cannot be made good rapidly ... the destruction is quasi-permanent' (Dow, 1998, p.369).

When opportunities for joint and cooperative labour are removed, income and expenditure (as well as training) are lost and expenditure loss reaches out from the economic base to embrace the service sector. Decline is contagious and cumulative in the absence of early and decisive response (Keynes, 1973a, p.225). When the economic base that defined communities withers, other doors also close. In major recessions previously created productive forces are destroyed and even vigorous, creative firms that might have had a lasting impact will perish (Schumpeter, 1943). Growth is not more of the same, so there is no point 'in trying to conserve obsolescent industries indefinitely', Schumpeter argues, but there are good economic and social grounds 'to avoid their coming down with a crash and in attempting to turn a rout, which may become a centre of cumulative, depressive effects, into orderly retreat' (Schumpeter, 1943, p.90). The idea that pace of decline matters is common sense and it connects to the Keynesian prediction that involuntary unemployment will always be 'troublesome [if] allowed to develop' (Keynes, 1973, p.118). Orderly retreat, regional balance, phased decline of dying industries, the role of the financial sector and credit in encouraging a new economic base, the importance of natural wastage in easing 
structural change and early response to employment loss did not inform the Counter Revolution..

In the early 1980s the combined effect of monetary and fiscal policy was severely contractionary (see Dow, 1998 and Treasury, 1981). Disinflation via gradual destruction of monetary demand, committed 'the government not to deal with a recession no matter how deep it [became]' (Okun, 1981, p. 358). Male unemployment in the United Kingdom increased by 8.2 percentage points between 1979 and 1986, reaching a peak of 13\%. By 1986, long-term unemployment (continuous unemployment of over one year) accounted for $45 \%$ of male unemployment and reached even higher proportions in the regions with the highest levels of unemployment. The decisive impact of deindustrialisation in enforcing substantial increase in spatial inequality is demonstrated in figure 2 . Whilst the IRC was not excluded from the effects of a changing industrial structure, male unemployment rose by 10 to 12 percentage points in the regions of severe deindustrialisation. The pattern is that deindustrialisation and unemployment increase concentrated on the regions where unemployment was high, even prior to recession. It is no surprise to discover that decline (like prosperity) can be self-perpetuating. Loss of work spreads through the economic base and loss of trade reaches out from the base to embrace the construction and local service sectors (see MacKay, 1994). Every kind of unemployment induces further unemployment is the Schumpeter emphasis (Schumpeter, 1939, p.515). Employment beyond the reach of those who are reduced by severe economic and social dislocation adds to unemployment and also encourages workers to drop out of the labour force.

Figure 2 goes here 
Weitzman (1982) argues that increasing returns to scale, interpreted broadly, is the key to understanding why the unemployed cannot produce on their own; and also why the 'self correcting forces' of the market are 'weak or non-existent' (Weitzman, 1982, p.804). The division of labour relies on plant and equipment designed for the joint use of a number of employees and builds from extension of the market. Moreover, productivity resides in the job and it depends on Adam Smith's joint and co-operative labour. Increasing returns also include external economies that connect to ease of contact and communication: to skills and know-how: to the emergence of specialist firms and working relationships within and between firms (see North, 1998). Physical and human capital - previously created productive power - is inherited. Loss of relevance can be sudden, devastating and have lasting effects. The destructive component of creative destruction is real and it hurts. There is an element of truth in Veblen's claim that the 'Right of Investment' confers 'a legal right' to sabotage employment and 'so make the community's workmanship useless' (Veblen, 1978, p.130). Specialisation implies interdependence. The earning power of the individual is at the mercy of a division of labour that adjusts to competitive forces beyond the control of the individual and the local community. With wealth can come uncertainty and unemployment and nonwork are 'a story about effective demand failures' that connect to increasing returns and specialisation (Weitzman, 1982, p.781).

Collective learning is North's term for the 'accumulated stock of knowledge' that emerges over time (see North, 1998, p84). Physical capital has specific properties and human capital develops particular skills. The essence of division of labour is that we cannot 'know, or do everything' (Richardson, 2002, p.38). Deindustrialisation is at the heart of unemployment increase in the early 1980s. But 
deindustrialisation and closure of firms is deeper than temporary loss of jobs. Given steep decline, there is loss of collective learning and loss of direction for capital and labour. Substantial checks to development may have lasting effects. Dow (1998) refers to loss of business confidence. Weitzman (1982, p.803) speculates that 'low expectations of aggregate demand become ingrained' and turn into a major cause of continuing low levels of activity. Collective learning includes the labour force. In households that lose contact with work children have a more difficult start in life and attitudes to school, further education, qualification, training, employment counselling and government placement are not uniform across labour markets. Ambition, involvement, commitment and aspiration expand with opportunity (Ashton and Maguire, 1986). Moreover, loss of jobs reduces training opportunities since learning by doing depends on work. One important consequence is that young adults lose out on the opportunity to build human capital at an important stage of their working lives.

The division of labour and increasing returns point to the importance of organic interdependence, the whole is more than the sum of the parts. The Keynesian Revolution placed strong emphasis on prompt and vigorous measures to encourage recovery when markets are lost. Severe, intense structural decline produces not only capital, but also human obsolescence. The reality is that the individual is given little indication of the forms of investment (response) that are likely to yield an acceptable return. Given severe decline it takes time and capital to provide a new direction for collective learning and employment. However, the longer the delay the more likely it is that cumulative forces of decline will be set in motion that prove difficult to check until they have run their course. Effective demand failures have an impact that reaches well beyond the short-run business cycle; the growth of the economy is path dependent. Dow (1998) claims that there is a significant reduction in productive 
potential in the 1980s and that this follows from recession and loss of confidence. Figure 3 shows that high levels of male claimant unemployment in 1986 translate into high levels of nonwork in 2001 (the correlation coefficient is 0.93). Male nonwork levels in 2001 vary from $16 \%$ of the work age population in IRC to $28 \%$ in the North East. The regional economies that suffer most heavily in the recession of the 1980s do not demonstrate strong powers of recovery. Figure 3 also shows the relationship between male regional unemployment in 1986 and male measured sickness in 2001. High levels of regional unemployment in 1986, convert into high levels of permanent sickness and disability in 2001 (the correlation coefficient is 0.88). By 2001, permanent sickness rates for non-student males of work age vary from over $11 \%$ in Wales, to less than $5 \%$ in IRC.

Figure 3 goes here.

Detached and/or discouraged workers are products of limited opportunity. Measured sickness is critical to loss of contact with work. The areas that 'experienced large scale job losses in the 1980s and 1990s, especially from traditional industries', dominate league tables for incapacity benefit and 'real' unemployment (see Beatty, Fothergill, Gore and Powell, 2007, p.12: also Table 1 p.13 and Table 4 p.23). Many of the locations that head these tables used to be heavily dependent on the traditional industries of mining, steel and ship building and large concerns dominated local labour markets. In both league tables there is strong geographical concentration, notably on Wales, the North East and North West. Beatty and Fothergill (2007) identify the continuing problems that flow from closure and job loss. Their survey evidence for incapacity benefit claimants in Barrow and Furness (major shipbuilding 
closures in early and mid 1990s) shows that those interviewed in 2007 were more demoralised and remote from the labour market than those interviewed in 1999. 'Initial willingness to consider employment [has been] gradually replaced by a complete detachment from the world of work, rationalised in terms of largely insurmountable health problems' (Beatty, Fothergill, 2007, p.616). The continuity of low levels of work is critical to our understanding of the movement from unemployment to inactivity in general and measured sickness in particular. Low levels of work do not add to labour quality and motivation and inability to compete in slack labour markets promotes a drift out of the labour force. Job loss ensured that 'sickness which was previously hidden became visible' (see Beatty, Forthergill, Macmillan, 2000 p.622). The realities of weak labour markets added to measured sickness and concealed unemployment in the last quarter of the $20^{\text {th }}$ century.

\section{Conflicting Objectives}

'There is ... a perplexing ... apparent asymmetry between Inflation and Deflation' (Keynes, 1973, p. 291).

'Our profession is in no small measure responsible for the confidently held view that public announcement of resolute irreversible monetary disinflation will so alter expectations in the private sector that our inherited wage and price inflation will melt like snow in spring sunshine. This proposition is not based on empirical evidence'. (Tobin, 1983, p.297).

The Keynesian asymmetry ensures that expansion beyond (or even short of) full employment will have a major effect on wages and prices. Deflation by contrast has a major effect on output and employment and a disappointing impact on wages and prices. Tobin's evidence to the Treasury Committee on Monetary Policy 
demonstrates that the Keynesian asymmetry has content. United States experience indicated that $90 \%$ of the year one response to a spending shock (cut) would end up in output reduction and only $10 \%$ in price reduction (see Treasury 1980-81, 163-II, Vol.2, question 760). Reducing entrenched inflation by monetary disinflation would entail deep cuts in output and large increases in unemployment. Tobin's carefully stated, but pessimistic view of the UK's 'interesting ... but risky experiment in macroeconomic and monetary policy' was strongly influenced by Okun's work on wage setting. Okun (1981) argued that wage bargaining developed in the context of a long-term relationship between firms and employees. Jobs are specialised and labour inside the firm is different to labour outside the firm. Implicit contracts (invisible handshakes) of indeterminate but often extended duration ensure that the labour market is not and cannot be an auction market (Okun, 1981). The unemployed cannot 'insist on being offered work', even if they would accept lower wages (Keynes, 1973, p. 291). Moreover, aggressive wage cutting is not the natural response of firms to excess supply of labour. The wage paid is important to the firm's reputation and standing in the labour market and fair treatment is designed to build morale and motivation. The wage is part of a long-term relationship that brings benefits to firms and workers.

Laidler claimed that "none of us [the us refers to monetarists] expected the implementation of a monetarist strategy ... to have significant adverse effects on output and employment, none of us expected the deep and prolonged depression that ensued.' (Laidler, 1985, p.35). There were clear warnings, not only from Tobin and Okun, but also from Galbraith and 364 academic economists who claimed that demand deflation would deepen depression and erode the industrial base (see The Times, $30^{\text {th }}$ March, 1981; for Galbraith, see Observer, $31^{\text {st }}$ August 1980 and Times, 
$3^{\text {rd }}$ March 1980). Deindustrialisation in the early 1980 s created a substantial regional divide, with that separation remaining powerful up to 2008. Figure 4 shows work levels (employment and self employment) per 100 men of work age in IRC and Wales and North ${ }^{\mathrm{ii}}$. In 1974 the work level in Wales and North was 88 jobs per 100 men of work age: in 2008 the work level was only 79 jobs per 100 men of work age. In the 1970s the work gap between Wales and North and IRC was modest, but by 1986 it was substantial.

Figure 4 goes here.

The normal pattern for UK recessions is that employment decline concentrates on the regions of low opportunity. However, the 1989-93 recession was the product of an unsustainable property boom that had been driven by unrealistic expectations of continued house price increases and employment loss was heavily biased towards the more prosperous parts of the country (Audas and MacKay, 1997). A speculative market that is driven by the psychology of the market rather than real values is not likely to prove consistently reliable. The recession of the early 1990s had a major impact on IRC work levels, a less pronounced effect on Wales and North. However, recovery in the most prosperous part of the country was impressive. By 2001 male work levels in IRC were not too distant from those experienced in the 1970s. In 2001, the work gap between Wales and North and the IRC was close to its highest level. Whilst a sustained period of economic expansion contributed to the narrowing of the work gap up to 2006, movement towards recession contributed to a widening of the work gap to 10 jobs per 100 men of work age by 2008 . 
Figure 5 shows output and earnings in Wales and North in relation to the IRC. Output per head in Wales and North was $85 \%$ of IRC level in the mid 70s, only $65 \%$ in 2008. The relative strength of the circular flow of output, income and expenditure shifts strongly against Wales and North. Most families are heavily dependent on income from work. Figure 5 shows that earnings, as well as work levels, move strongly against Wales and North. In 1979, Wales and North male earnings in fulltime work were $92 \%$ of the IRC level, by 2008 only $77 \%$. In the years $1973-79$ the average wage in rest of UK was $91 \%$ of the IRC level; in the years $1980-89$ the average fell to $86 \%$; in the years $1990-2001$ the average fell to $80 \%$; and in the years since 2001 the average has fallen again to $76 \%$. The large work gap is accompanied by a substantial and growing wage gap. In a buyers' market for labour, (low levels of opportunity) firms can place a greater reliance on casual and contract work (see Tilly and Tilly, 1998). The weaker the labour market the more likely it is that employers offer unattractive work at low wages and hire workers for short-run jobs. 'The employers survive only because they can thrust the burden of unstable business on a casual labour force' (Solow, 1982, p. 158). Different levels of reliance on unstable and low wage employment are important to our understanding of the growing regional disparities that are illustrated in Figure 5.

Figure 5 goes here. 


\section{Conclusions}

'If, as Smith maintains, the division of labour maximises the development of very specialised skills, it also greatly increases the risk of losing much human capital if a particular occupation becomes redundant' (Pagano, 2003, p.636)

Questions of practical policy monopolised Keynes' considerable abilities. He was convinced that we should not tolerate the levels of unemployment that emerged from 'capitalistic individualism' in the 1930s (Keynes, 1973, p. 381). There was, he argued, no automatic market mechanism that would ensure full employment. This was true, even if wages and prices were fully flexible and Keynes consistently worked against those who blamed the depression of the 1930s on high wages for labour. Stabilising an unstable system is difficult and fine-tuning is not a serious possibility, but there needs to be some method for guiding the 'invisible hand'. Automatic stabilisers (tax reductions and public expenditure increases in recession) became the natural substitutes for the 'invisible hand' of the market in the post-war years.

History matters in two senses. First, past events have a lasting influence. Second, what works and is appropriate at one stage of economic evolution may be ineffective later. There are two relevant examples. First, relocation of industry depended on manufacturing expansion and also full (or over full) employment in prosperous regions. Second, post-war reconstruction, cheap oil and wage restraint encouraged by the memory of the Great Depression provided a favourable environment for demand management in the Keynesian Golden Age. Keynes was well aware that a move to sustained full employment would, in time, breed its own new needs, problems and demands. Hicks argued that economic policy had adopted a dangerously rigid 'labour standard' in the post-war years when maintenance of full 
employment became, if not the only desirable objective, certainly the litmus test that came before all others (Hicks, 1955).

In later years an inflation standard and free market fundamentalism substituted for the 'labour standard'. A cautious approach to macroeconomic policy has a major effect on real as well as nominal (price) variables. The steep rise in unemployment and the significant shift to spatial inequality takes place in the years 1979-86 (see Parts 3 and 4). Regional unemployment increases connect to deindustrialisation and low opportunity regions do not demonstrate strong powers of recovery in later years. The connections are unlikely to be the product of chance. The size of the market determines the development of capital and increasing returns to scale (internal and external) ensure that "change [growth and decline] becomes progressive and propagates itself in a cumulative way' (Young, 1928, p.533). Cumulative causation accounts of economic development point to the possibility of growing regional imbalance. The economically successful regions generate profits and easy access to credit and these will encourage further investment (Sawyer, 1995; MacKay and Molyneux, 1996). There is an ever present danger that markets will tend to settle demand and new growth on the wrong places (Beveridge, 1944).

Employability is not independent of employment and it is difficult to encourage transfer when there is little to transfer to. Early response to job loss is critical if we seek to avoid cumulative decline. High levels of nonwork connect to collapse in the underlying industrial structure. Loss of work is 'a serious disruption in workers' lives', it leaves a gap, or space, that communities, families and individuals struggle to bridge (Piore, 1987, p.1836). The problems that follow from loss of work connect to community and social values and there are problematic inter-generation effects. Disguise and camouflage of measured unemployment has added to the costs 
of dependency (sickness benefit is more generous than unemployment benefit) and has encouraged lasting divorce from the labour market.

The evolution of an appropriate institutional structure for mixed economies is not a narrow, technical problem (see Sawyer, 1995; Minsky, 1986). There is, Kalecki warned, a difficult political economy problem that connects to full employment and its shift in the balance of power: the political function of sound finance and low inflation is to ensure that economic policy is driven by the short-term needs of business (see Kalecki, 1943; Sawyer, 1995). The Keynesian Revolution was not a sudden flash of revelation. Keynes was a careful observer and his ideas, thought patterns and General Theory evolved over time, in response to the evidence of instability provided by the Great Depression. Even more important, the Keynesian Policy Revolution (with its combinations of public and private, collective and individual) owed much to post-war cohesion and a sense of shared sacrifice and purpose. The values, attitudes and power structures that inform the Counter Revolution to Keynes are notably different, but there are three important themes we can touch, if not fully explore.

A ‘wisely managed' capitalism would, Keynes (Keynes, 1973a, p.294) predicted, be notably more effective in delivering goods and services than any alternative system on offer. He did, however, stress that the good life and the responsible society depended on more than output and wealth. As we grow more productive and affluent, the important tests for mixed economies connect to the opportunities they offer workers and citizens 'to develop their own potential, express their identity and create their own future' (Bronck, 2009, p.305; Keynes, 1973a, p.326-332). The second theme comes from Schumpeter. An economic system that uses resources of given potential effectively is not necessarily ideal in developing 
resources whose potential is unknown. Schumpeter drew attention to the ruthless and unstable energy of capitalism. 'Our capacity to innovate and make the right moves in the endless battle to create the next generation of dominant goods [and services] and technologies is far more important in the long run than the efficient allocation of today's resources' (Bronck, 2009, p. 302-3). The third theme is that a sensible political economy would recognise that the untempered operation of markets has to be moderated by intervention. Unemployment (open and disguised) is an economically and socially inefficient control mechanism (Keynes, 1973a, pp. 86-125). Moreover, markets have limits and economics is not confined to market solutions. There is no grand theory that decides the balance between private and public, but there are products and services that markets do not provide effectively and efficiently (Keynes, 1973a pp.272-94). Private investment and private insurance are not consistently more reliable than public investment and social insurance. The substitution of private monopoly for private monopoly can add to capital cost, to contracting cost, to uncertainty. The rules of engagement are different in public and private sectors precisely because nonwork is expensive for the economy and the tax payer.

Schumpeter and Keynes both claimed that forms of investment 'more suited for public than ... for private enterprise' have an important stabilising role (Schumpeter, 1943, p.120).

Loss of confidence, increase in uncertainty, reluctance to invest, the dimming of animal spirits and a shift from boom to bust should not come as a complete surprise in capitalist economies. Loss of direction increases when 'enterprise becomes the bubble on a whirlpool of speculation' (Keynes, 1973, p.159). There are deep problems when speculation crowds out investment in 'nationally productive channels' (Keynes, 1973a, p292). Schumpeter (1934, p.116) makes a similar point when he 
argues that the all important function of credit and capital is to 'divert the factors of production to new uses [and so dictate] a new direction to production'. The Keynes/Schumpeter observations connect to recent claims that the financial sector has become irresponsible and socially useless. A successful, balanced economy capable of generating new opportunities requires a financial system which serves the needs of the productive sector, not vice versa (see Sawyer 1995)

Adam Smith argued that 'the love of our country seems ... to involve ... an earnest desire to render the conditions of our fellow-citizens as safe, respectable and happy as we can' (Smith 1759, p.231). Sympathy and empathy, as well as self interest, are important components of human interaction. Those who argue for market forces on the grounds that they create sufficient income to spread throughout society have been slow to recognise that the discipline of individual contribution, if strictly applied, works strongly against certain groups in society, including those at some disadvantage in the labour market. Minsky's value judgment is relevant, 'the humane objective of stabilization policy is to achieve a close approximation to full employment' (Minsky, 1986, p. 308). In the years following the Keynesian Golden Age, instability, insecurity, inequality and underemployment increased. Without some sympathy for those displaced by structural decline, closure and redundancy there is little substance to the nation state or to regional balance. 


\section{BIBLIOGRAPHY}

Audas R.P., MacKay R.R. (1997) A Tale of Two Recessions, Regional Studies, 31, 867-874.

Ashton D.N. and Maguire M.J. (1986) Young Adults in the Labour Market, Department of Employment Paper, No. 35

Beatty C., Fothergill S., Gore T. Powell R. (2007) The Real Level of Unemployment, Sheffield Centre for Regional Economic and Social Research.

Beatty C., Fothergill S., (2007) Changes in the Profile of Men Claiming Incapacity Benefit - A Case Study, Centre for Regional Economics and Social Research.

Beatty C., Fothergill S., Macmillan R. (2000) A Theory of Employment, Unemployment and Sickness, Regional Studies, 34, 617-30.

Beveridge W.H. (1944) Full Employment in a Free Society, Allen Unwin: Hemmel Hempstead.

Bronck R. (2009) The Romantic Economist, Cambridge UP, Cambridge.

Dow C. (1998) Major Recessions: Britain and the World, Oxford University Press, Oxford.

Dow J.C.R. (1964) The Management of the British Economy, Cambridge UP: Cambridge.

Friedman M. (1977) Friedman on Galbraith, Institute of Economic Affairs, London. Hennessy D. (1993) Never Again, Britain 1945-51, Vintage.

Hicks J. R. (1955) Economic Foundations of a Wage Policy, Economic Journal, 65, $389-404$.

Hume D. [1752] (1963) J.B. Stewart (ed) The Moral and Political Philosophy of David Hume, Columbia UP, New York. 
Kalecki M. (1943) Political Aspects of Full Employment, Political Quarterly, Vol. 14, pp. 322-31.

Keynes J.M. [1936] (1973) The General Theory of Employment, Interest and Money, Collected Writings of J.M. Keynes, Vol. 7, Cambridge UP Macmillan, London.

Keynes J.M. (1973a) Essays in Persuasion, Collected Writings of J.M. Keynes, Vol. 9, Cambridge UP Macmillan, London.

Keynes J.M. (1973b) How to avoid a slump. Times 12-14 Jan 1937 in Collected Writings of J.M. Keynes, Vol. 21, Cambridge UP Macmillan, London.

Keynes J.M. [1937] (1973c) The General Theory and After: Part 2 Defence and Development, Collected Writings of J.M. Keynes, Vol. 14, Cambridge UP Macmillan, London.

Laidler D. (1985) Monetary Policy in Britain: Successes and Shortcomings, Oxford Review of Economic Policy, 1(1) 35-43.

Läpple D. (1985) Internationalization of capital and the regional problem, in J. Walton (ed), Capital and Labour in the Urbanized World, pp. 43-75, Sage: London.

Luttrell W.F. (1962) Factory Location and Industrial Movement, NIESR, London. MacKay R.R., Thomson L. (1979) Important Trends in Regional Policy and Regional Employment - A Modified Interpretation, Scottish Journal of Political Economy, 26, 223-60.

MacKay R.R. (1994) Automatic Stabilisers, European Union and National Unity, Cambridge Journal of Economics, 18, 571-85.

MacKay R.R., Davies L. (2008) Unemployment, Permanent Sickness, and Nonwork in the United Kingdom, Environment and Planning A, 40, 464-81. 
MacKay R.R., Molyneux P. (1996) Bank Credit and the Regions: A Comparison within Europe, Regional Studies, 30:8, 757-63.

Maddison A. (1991) Dynamic Forces in Capitalist Development, Oxford UP, Oxford.

Minsky H.P. (1986) Stabilising an Unstable Economy, Yale UP, New Haven.

North D.C. (1998) Economic performance through time, in Eicher C.K. and Staatz J.M. (eds) International Agricultural Development, Third Edition, John Hopkins; Baltimore, 78-89.

Okun A.M. (1981) Prices and Quantities: A Macroeconomic Analysis, Basil Blackwell, Oxford.

Orwell G. (1980) The Road to Wigan Pier, in George Orwell, Collected Works, Octopus Books, London, 123-231.

Pagano U. (2003) Nationalism, development and integration: the political economy of Ernest Gellner, Cambridge Journal of Economics, 27, 623-404..

Phelps Brown (1983) Origins of Trade Union Power, Clarendon Press, Oxford.

Piore M.J. (1987) Historical perspectives and the interpretation of unemployment, Journal of Economic Literature, Vol. XXV, pp. 1834-50.

Richardson G.B. (2002) Mrs Penrose and Neoclassical Theory, in Pitelis C. (ed) The Growth of the Firm: The Legacy of Edith Penrose, Oxford UP, Oxford, 37-59.

Rowthorn R. Webster D. (2008) Male Worklessness and the Rise of Lone Parenthood in Great Britain, Cambridge Journal of Regions, Economy and Society, 1, 6988.

Salter W.E.G. (1969) Productivity and Technical Change, Cambridge UP, Cambridge. 
Sawyer M. (1995) Obstacles to Full Employment in Full Economies, in Arestis P. and Marshall M. (eds), The Political Economy of Full Employment, Edward Elger, Aldershot, p. 15-35.

Schultz T.W. (1961) Investment in Human Capital, American Economic Review 51, $1-17$.

Schumpeter J.A. (1934) The Theory of Economic Development, Harvard UP, Cambridge, Mass.

Schumpeter J.A. (1939) Business Cycles, McGraw-Hill, New York.

Schumpeter J. A.(1943) Capitalism, Socialism and Democracy and the World, Unwin University Books.

Smith [1776] (1904) The Wealth of Nations, E. Cannon (ed), Methuen: London.

Smith A [1759] (1984) The Theory of Moral Sentiments, ed by Raphael and Macfie, Liberty Fund, Indianapolis.

Solow R.M. (1982) What Happened to Full Employment? in Reynolds G.G., Masters S.H. Moser C.H. (eds) Readings in Labor Economics and Labor Relations, Prentice-Hall, New Jersey.

Tilly C. and Tilly C. (1998) Work Under Capitalism, Westview Press, Boulder Col. Tobin J. (1983) Macro-Economics Prices and Quantities, Basil Blackwell, Oxford. Treasury and Civil Service Committee, (Session 1980-81 Monetary Policy, HCP 1631, 163-II, 163 -III).

Veblen T. (1978) The natural right of investment, in MacPherson C.B. (ed) Property, Mainstream and Critical Positions, Basil Blackwell; Oxford, 118-32.

Weitzman M.L. (1982) Increasing Returns and the Foundation of Unemployment Theory, Economic Journal, 92, 787-804. 
Worswick D. (1992) How was it possible to run economics at such high pressure without accelerating Wage Rates, in Cairncross C., Cairncross F. (eds) The Legacy of the Golden Age. Routledge, London 15-63.

Young A. (1928) Increasing Returns and Economic Progress, Economic Journal, 38, $527-42$. 
Table 1: IRC Compared with Wales and North

\begin{tabular}{|c|c|c|}
\hline & $1974-75$ & $2000-01$ \\
\hline Output per Head $^{\mathrm{a}}$ & $84 \%$ & $69 \%$ \\
\hline Male Earnings ${ }^{\mathrm{a}}$ & $92 \%$ & $79 \%$ \\
\hline Household & $86 \%$ & $78 \%$ \\
\hline \multicolumn{3}{|l|}{ Expenditure $^{\mathrm{a}}$} \\
\hline & 1971 & 2001 \\
\hline \multicolumn{3}{|l|}{ Male Work Level $^{\mathrm{b}}$} \\
\hline GB & $91.6 \%$ & $80.2 \%$ \\
\hline IRC & $93.2 \%$ & $83.7 \%$ \\
\hline Wales and North & $90.4 \%$ & $75.1 \%$ \\
\hline Work Gap & $2.8 \%$ & $8.6 \%$ \\
\hline \multicolumn{3}{|l|}{ Male Unemployment Level ${ }^{\mathrm{c}}$} \\
\hline GB & $5.2 \%$ & $5.3 \%$ \\
\hline IRC & $4.1 \%$ & $4.6 \%$ \\
\hline Wales and North & $6.7 \%$ & $6.2 \%$ \\
\hline Unemployment Gap & $-2.6 \%$ & $-1.6 \%$ \\
\hline
\end{tabular}

Notes:

a) Wales and North as a percentage of IRC

b) Employment and self employment as a percentage of non-student working age population 
Table 2 UK Unemployment - 3 Steps to a Buyers' Market for Labour

\begin{tabular}{|c|c|c|}
\hline Years & $\begin{array}{l}\text { Male Claimant } \\
\text { Unemployment } \\
\text { Rate }\end{array}$ & Comment \\
\hline $1950-67$ & $1.8 \%$ & $\begin{array}{l}\text { Sellers' market for labour. Annual } \\
\text { unemployment never above Beveridge target of } \\
3 \%\end{array}$ \\
\hline $\begin{array}{l}\text { Step } 1 \\
1968-72\end{array}$ & $3 \%$ & $\begin{array}{l}\text { The years following the Phelps Brown hinge, or } \\
\text { tipping point, with unemployment above } 3 \% \text { in } \\
1971 \text { and } 1972\end{array}$ \\
\hline $\begin{array}{l}\text { Step } 2 \\
1973-79\end{array}$ & $4.7 \%$ & $\begin{array}{l}\text { The years following the first OPEC recession, } \\
\text { with unemployment below } 3 \% \text { in only } 2 \text { years. }\end{array}$ \\
\hline $\begin{array}{l}\text { Step } 3 \\
1980-86\end{array}$ & $11.3 \%$ & $\begin{array}{l}\text { The years following the second OPEC recession } \\
\text { and including major deindustrialisation. } \\
\text { Unemployment more than } 6 x \text { the } 1950-67 \\
\text { average and Long-Term unemployment a } \\
\text { growing proportion of the unemployed. }\end{array}$ \\
\hline
\end{tabular}


Figure 1: Work, Permanent Sickness and Unemployment: 2001

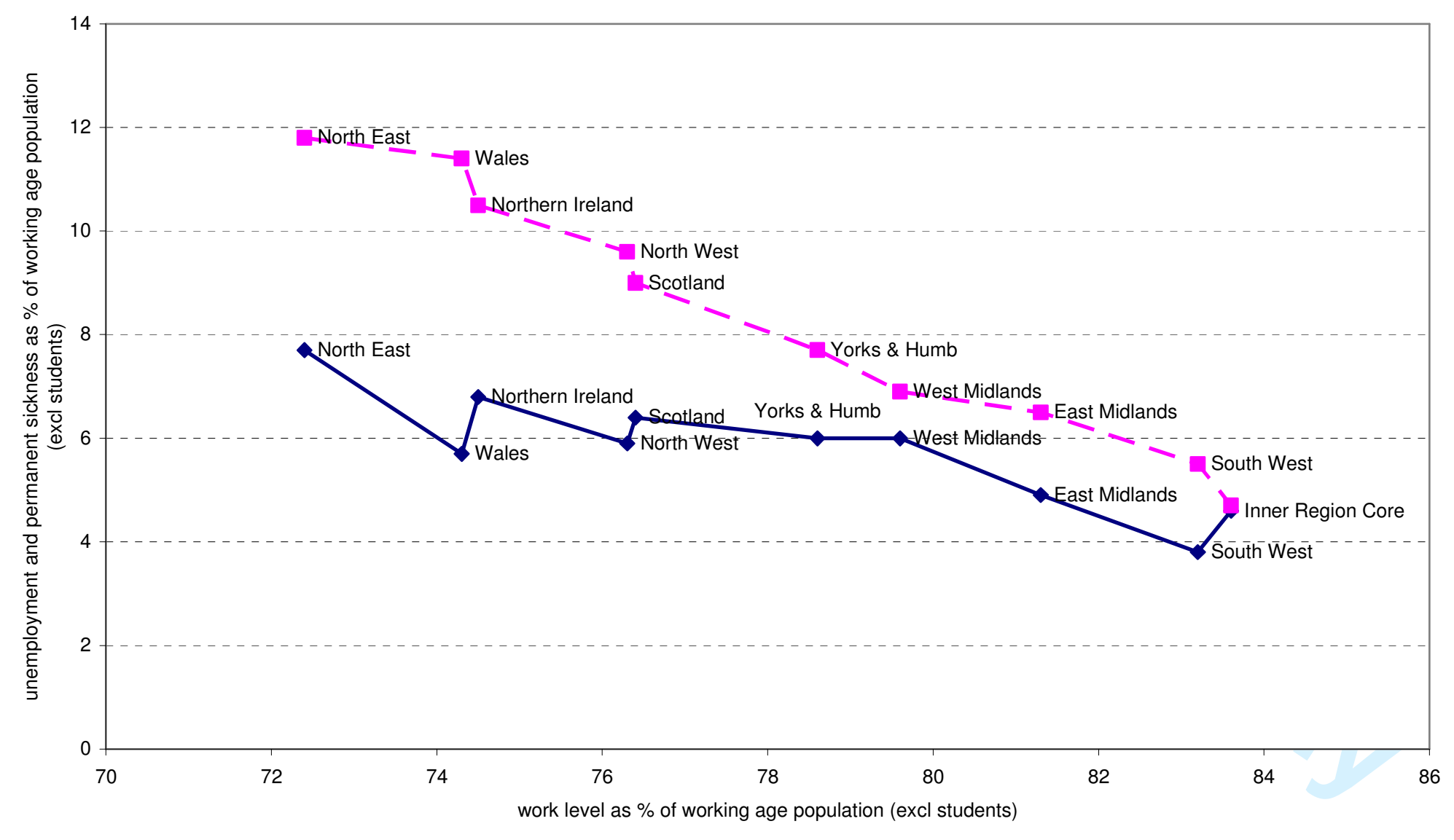

$\longrightarrow$ Unemployment $\longrightarrow-$ Permanent Sickness

Source: 2001 Census 
Figure 2: Deindustrialisation and the Growth of Unemployment

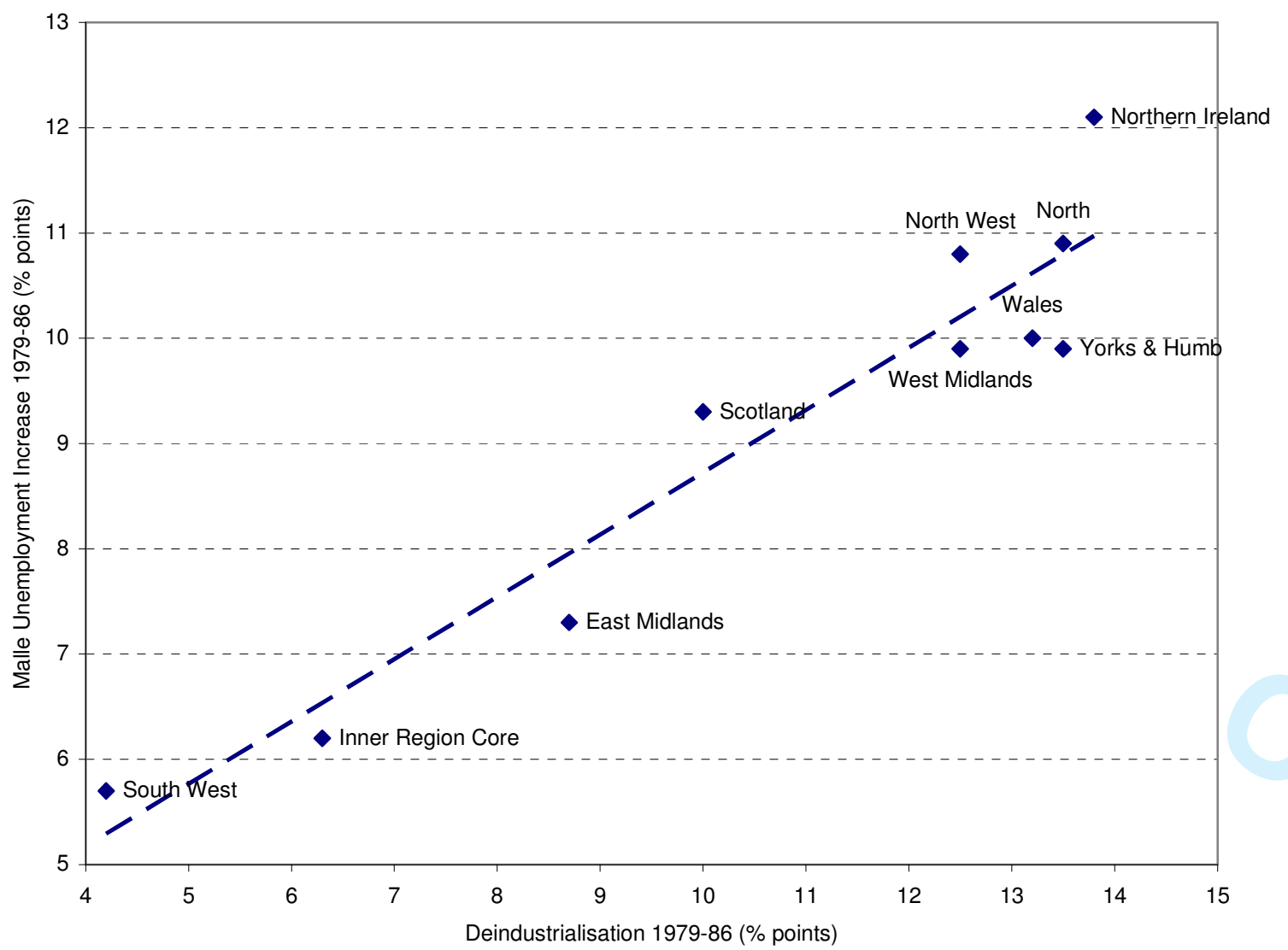

Source: Employment Gazette

Notes: Deindustrialisation is defined as reduction in production industries between 1979 and 1986 as percentage of total employment in 1979. Increase in unemployment is based upon the claimant count. 
Figure 3: Regional Continuity in Male Unemployment and Non-Work

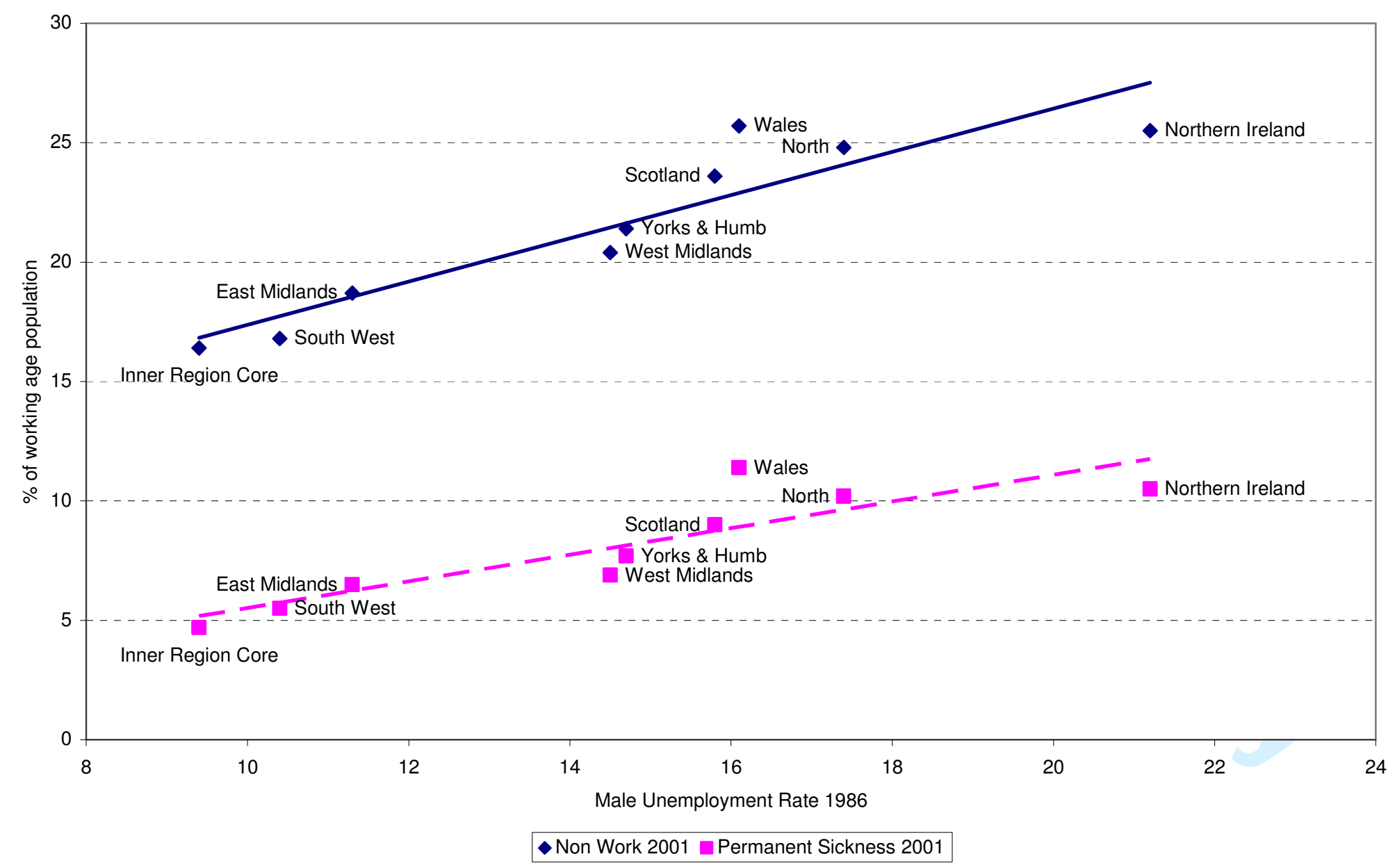

Source: Employment Gazette, 2001 Census. 
Figure 4: The Evolution of the Male Employment Gap

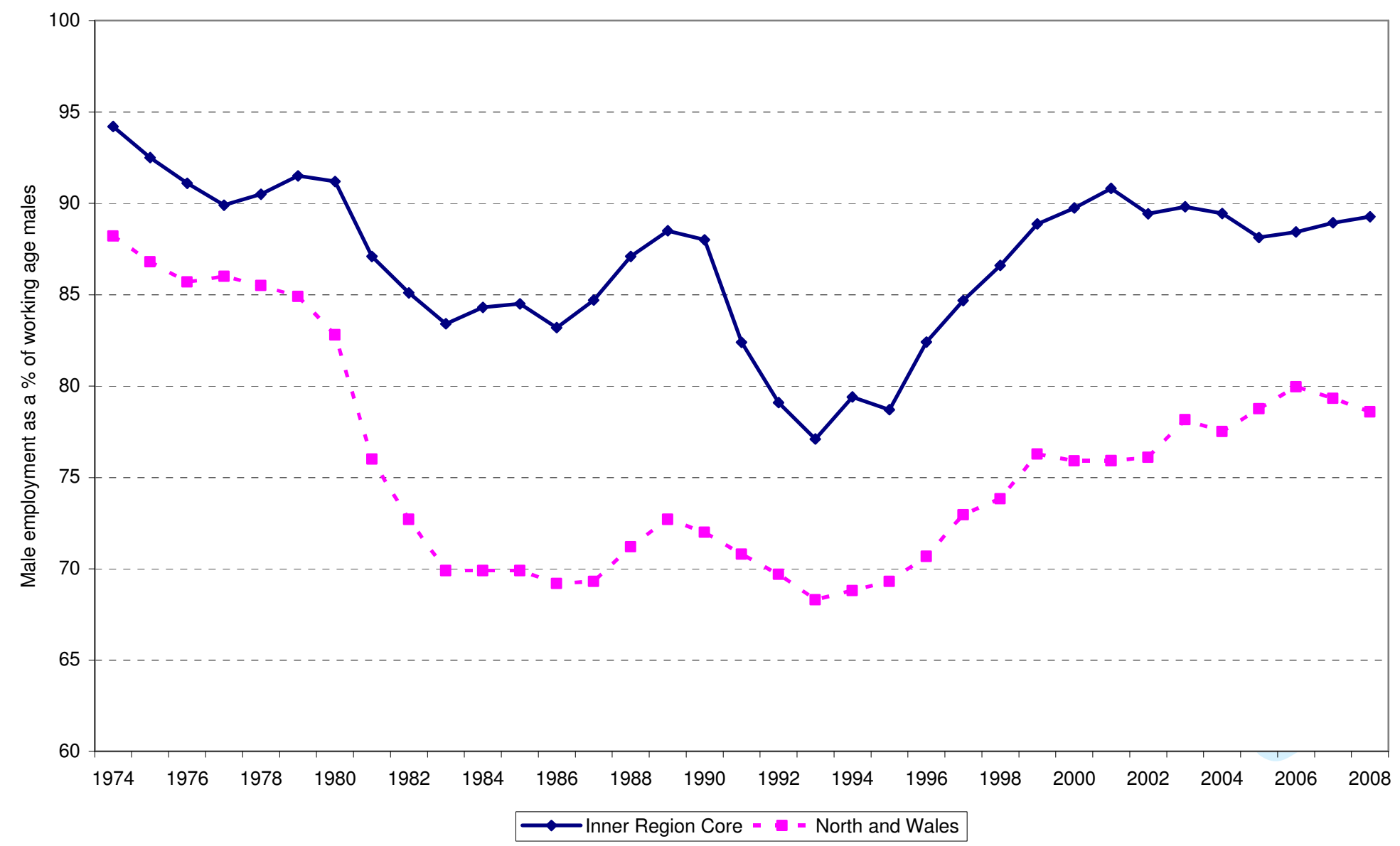

Source: Workforce in Employment, Employment Gazette; Mid-Year Population Estimates, NOMIS

http://mc.manuscriptcentral.com/cres Email: regional.studies@fm.ru.nl 
Figure 5: Earnings and Output Inequality

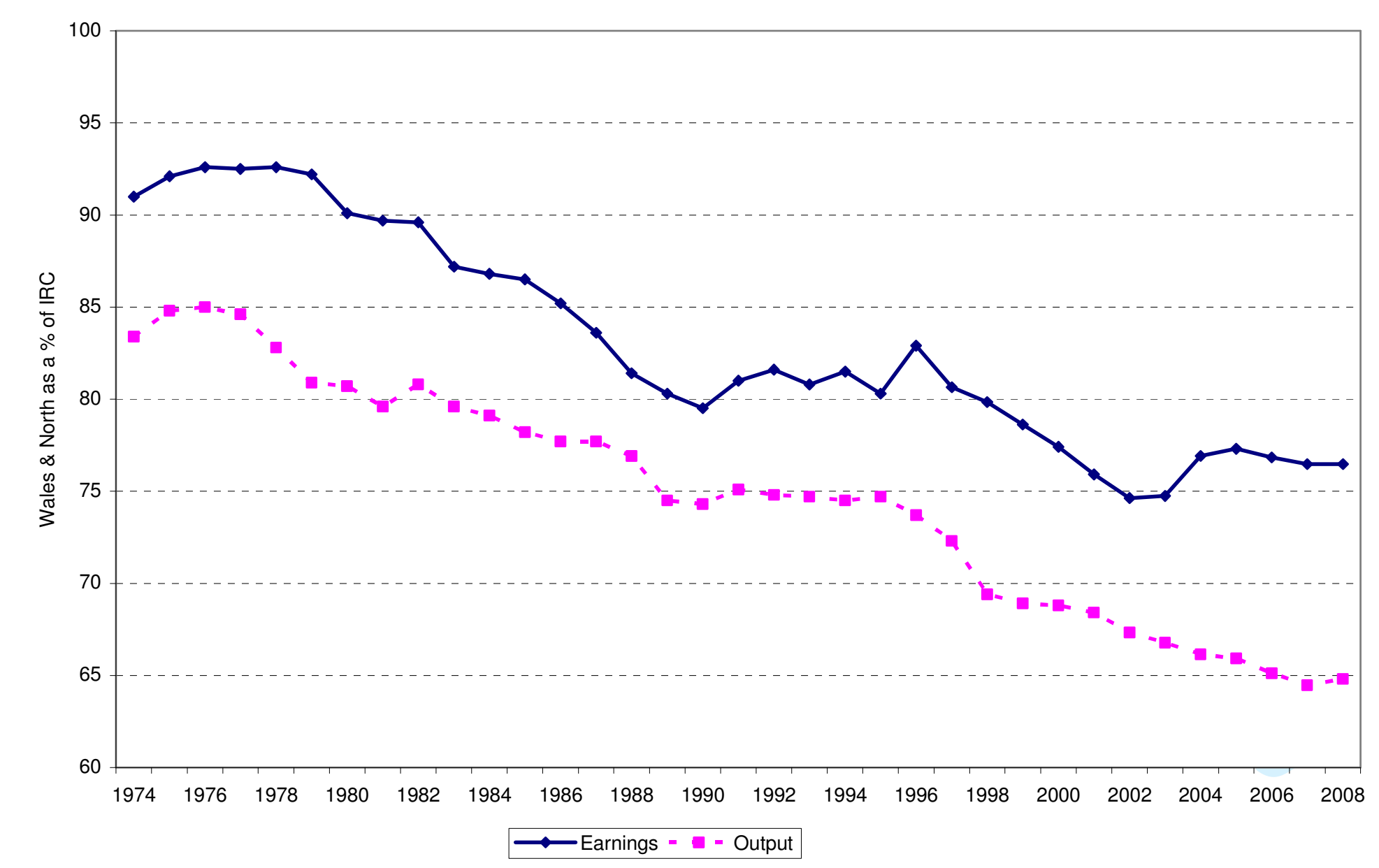

Source: New Earnings Survey, Annual Survey of Hours and Earnings, Regional Trends, ONS Time Series

http://mc.manuscriptcentral.com/cres Email: regional.studies@fm.ru.nl 


\begin{abstract}
${ }^{\mathrm{i}}$ In 1971, the Census Unemployed are those without work who are seeking and available for work. In 2001, the Census Unemployed are those who are not in employment, are available to start work within the next 2 weeks and have either looked for work in the last 4 weeks or are waiting to start work. This is equivalent to the ILO definition. ILO and Census Unemployment are higher than the numbers claiming unemployment related benefits in the UK - the 'Claimant Count'.

ii Derived from Estimates of the Workforce in Employment, some men have two jobs and some jobs are taken by men aged over 64.
\end{abstract}

